\title{
FÜRDŐTURISTÁK ELKÖTELEZETTSÉGEINEK ÉS PREFERENCIÁINAK VIZSGÁLATA A NYUGAT-DUNÁNTÚLON
}

\author{
Szabó Zoltán
}

\section{Összefoglalás}

Az elmúlt években az egészség felértékelódése által a turizmus felismerte a gyógyvizre alapozott gyógyturizmus fontosságát, ezért egyre növekszile az érdeklódés a gyógyfürdö-szolgáltatásokat igénybe vevök. jobb megismerése iránt. Jelen tanulmány arra törekszike, hogy hozzájáruljon a fürdóbe járó gyógyfürdözók. fogyasztói magatartásánake eddigi sұükös kutatásáboz. Konkerétan a gyógyfürdö-szolgáltatások igénybevételének összefüggés-vizsgálatát tárja fel a fürdökedveló felnôtt magyar turisták körében a szocio-demográfiai jellem zôke felhasználásával. Ehhez kérdốves felmérést végeztem, az adatfeldolgozásához egyváltozós leiró statisztikai és kétváltozós kereszttábla elemzéseket has ználtam. A kapott eredményekböl hat olyan megállapitás követkeqiik, melyek a turizmus tervezóinek az új piaci lehetöségek jobb kihasználásában, a fürdömened ssereknek a vendégigények. jobb kielégitésben és a batékony fürdóüzemeltetésben nyüjthat segitséget.

Kulcsszavak: Fogyasztói magtartás, fürdöszolgáltatások, fürdökedvelö, gyógyhely, turizmus JEL: I31, J10, L68, M21, Z30

\section{EXAMINATION OF BATH TOURISTS COMMITMENT AND PREFERENCE IN THE WEST PANNON}

\begin{abstract}
In the last years trought the apperciation of health the tourism recognized the importance or health tourism based on medical water. Therefore there is a growing interest to know the uses of medical spa services. Aim of the study to contribute the limited research on the consumer behavior of the medical spa services. Specifically, the study explores to use of spa services among adult Hungarian tourists, with using socio-demographic characteristics. To this, I conducted a questionnaire survey and used univariate descriptive statistics and bivariate crosstable analyze for data processing. Six statement follows from the results, which help to the tourism planners make better use of new market opportunities, to the spa managers make better meet guest needs and in effective bath management.
\end{abstract}

Keywords: Consumer behavior, Health Resort, Spa Loving, Spa Services, Tourism JEL: I31, J10, L68, M21, Z30 


\section{Bevezetés}

Az elmúlt évtizedekben az egészség javításával kapcsolatos turisztikai utazások világszerte egyre népszerűbbé váltak, mert felértékelődött az egészség, mely az ember legértékesebb tulajdonsága. Közismert, hogy az elhanyagolt egészség jelentősen rontja az életminőséget, ezért egyre több ember számára fontos az egészség megőrzése illetve javítása (Kopp, 2007; Riskin, 1996). Azok a személyek, akik egészségtudatos életmódot folytatnak, egyre jobban érdeklődnek az egészséggel kapcsolatos termékek és szolgáltatások iránt (Printz-Markó, 2019; Mühlhausen, 2001; Kraft, 1993).

Az egészségturizmushoz kapcsolódó utazások a szükséges kezelések megszerzése érdekében lehetnek megelőző-, gyógyító (orvosi) vagy utókezelés-orientáltak (Hojcska, 2019a). Következésképpen az egészségturizmus úgy határozható meg, hogy a turista a lakóhelyről egy másik helyre utazik azért, hogy az egészséggel kapcsolatos szolgáltatásokat igénybe vegye (Printz-Markó-Albert-Tóth, 2018; Hojcska, 2017a; Bauer, 2008). A prognózisok szerint a magyar lakosság egyre növekvő hányada ismeri fel, hogy a megfelelő egészségi állapot az alapja a munkatermelékenységnek, az emocionális, intellektuális és fizikai fejlődésnek (Botos-Kovács, 2018; Baji, 2015).

Magyarországon az 1990-es években végbement társadalmi és gazdasági átalakulás befolyásolta az egészségturisztikai létesítmények állami támogatással történő fejlesztését (Nemes, 2009), melyek a fejlett országok legjobb egészségturisztikai központjainak szolgáltatási színvonalát célozták meg (Jandala et al. 2010).

A 2001. évtől a fejlesztések új lendületet vettek (Dávid et al., 2007; Bujdosó, 2016; BujdosóGyurkó-Benkő, 2019), melynek eredményeként új fürdőkomplexumok, gyógy- és wellness szállodák épültek, valamint a korábban építetteket felújították, fejlesztették (Mundruczó-Szennyessy, 2005; Budai-Székács, 2001). A fejlesztések következtében Magyarországon számos fürdőkomplexum található, melyekben a nemzetközi gyakorlatnak megfelelően élményfürdő, strandfürdő és gyógyfürdő található, amelyek turisztikai szempontból jelentős forgalmat bonyolítanak le (Hojcska, 2019b; KSH, 2013).

A témával kapcsolatos szakirodalom egyetért abban, hogy a természeti tényezőkre alapozott gyógyturizmus fejlesztése alapvetô kitörési pontja a turizmusnak (Lővei-Kalmár, 2018; Li et al. 2017, Kincses, 2014; Kulcsár, 2013; Garcia-Altes, 2005; Guld et al, 2019; Németh-Farkas, 2005). Magyarország a kiemelkedően kedvező gyógyvíz ellátottságából adódóan a gyógyfürdő-szolgáltatások piacának növekvő fontosságú szereplője lehet, ehhez azonban alapvető fontosságú a belföldi piac kiegyensúlyozottsága és biztonsága (Bujdosó-Györki, 2011; Bíró et al. 2019). A téma aktualitását az adja, hogy a magyarországi gyógyturizmus keresleti piaca még nem teljesen ismert, ugyanis az eddigi kutatások nem terjedtek ki a fürdőkomplexumon belül a fürdőrészlegek szolgáltatásigénybevételének összefüggés-vizsgálataira, ezért ez a tanulmány hiánypótló. A téma újszerűségét az adja, hogy a kutatás eredményeinek segítségével az egészségturizmus magyarországi tervezése és fejlesztése elősegíthető, másrészt a fürdőmenedzsment számára támogatást nyújt az új technikák bevezetésében, a költséghatékony megoldások, valamint a szolgáltatásnyújtás méretgazdaságosságának a kialakításában (Boros et al. 2012).

A kutatás célja, hogy a fürdőkedvelő kehidakustányi fürdőturisták körében feltárásra kerüljön a Kehida-Termál Gyógy- és Élményfürdő gyógyfürdő-szolgáltatások iránti elkötelezettségük és preferenciájuk. Ezek ismerete segítséget nyújthat a turizmus tervezőinek az új piaci lehetőségek jobb kihasználásában, a fürdőmenedzsereknek a vendégigények jobb kielégítésben és a hatékony fürdőüzemeltetésben. 


\section{Kehidakustányi fejlesztések a fürdöturizmus erösítése érdekében}

Kehidakustány Magyarország nyugat-dunántúli régiójában, Zala megye északi részén, Keszthelytől 24 kilométerre, a megyeszékhely Zalaegerszegtől 30 kilométerre, nemzetközi hírú fürdővárosok vonzásában (Hévíz 14 km, Zalakaros 32 km) helyezkedik el (Hojcska, 2017b). Kehidakustány három, egykoron önálló falucskából Kehida, Kustány és Barátsziget községekből alakult ki (Szóládi, 2003). Kehida egykor a megye központi szerepét töltötte be, mivel fekvése révén alkalmas volt, hogy Zala vármegye nemesei rendszeresen itt gyúljenek össze. Kehida első írásos emléke 1232-ből származik, mely a történelem során több neves családdal is összefonódott, mint a Koppányi család, a Kanizsai család, a Deák család, a Hédervári család, a Szentkirályi család, a Széchenyi család és a Károlyi család) (Mészáros, 2007). Kustány első írásos említése egy 1181. évi oklevélben található, önállóságát pedig 1977-ben Kehidával történő összevonása során veszítette el. Barátszigetet 1939ben egyesítették Kehidával (Dominkovits et al. 2007). Kehidakustányban 1978-ban ivóvízbázis után történő kutatás során 203 méter mély fúrt kútból 49,0 ${ }^{\circ} \mathrm{C}$-os, kimagaslóan magas kalciummagnézium-hidrogénkarbonátos termálvizet nyertek. A víz turisztikai célú felhasználása érdekében 1985-ben 6 db szabadtéri fürdőmedencét, 1986-ban további hidegvizes úszómedencét építettek (Fejér, 2015). Ettől kezdve a turisták májustól szeptemberig nagy számban látogatták a termálfürdő létesítményeit. A termálfürdőt üzemeltető-tulajdonos Kehidakustány Község Önkormányzata 1998-ban abba a helyzetbe került, hogy a jelentős bevételi forrást biztosító fürdőt nem volt képes gazdaságilag hatékonyan üzemeltetni a turizmus változó igényeinek megfelelően. Ekkor fogalmazódott meg Kehidakustány Község Önkormányzatának azon településfejlesztési célja, hogy Kehidakustány kiváló környezeti adottságai révén, valamint a termálvíznek köszönhetően nemzetközi szintű gyógyturisztikai és rekreációs kínálatot alakítson ki. A cél elérése érdekében Kehidakustány Község Önkormányzata 2000-ben a termálfürdő üzemeltetésére és fejlesztésére a Kehida Termál Kft.-vel haszonbérleti szerződést kötött.

A Kehida-Termál Gyógy- és Élményfürdő átfogó fejlesztése négy, egymásra épülő ütemben zajlott.

Az első ütem 2000. december 16-án alapkő letételi ünnepséggel vette kezdetét, melynek eredményeként 32 darab négy csillagos szállodai szoba, a Deák étterem, az önkiszolgáló étterem, a kávézó valamint nyolc üzlethelyiség, menedzsment irodák, egy 100 férőhelyes konferenciaterem és egy 600 férőhelyes öltöző épült meg. Az első ütem bekerülési értéke 927 millió forint volt, melyből a támogatás összege 150 millió forint, a hitel értéke 320 millió forint és a saját erő 457 millió forint volt.

A Széchenyi Terv pályázati rendszeréhez 2001-ben benyújtott, a termálfürdők fejlesztésére, illetve kialakításának támogatására, valamint a kapcsolódó infrastrukturális és környezeti fejlesztés támogatására benyújtott SZT-TV-1/01/03/02 számú pályázat alapján elnyert 640 millió forint támogatás biztosított fedezetet a második és harmadik ütem megépítésére. A fejlesztés eredményeként valósult meg a gyógyászat és a fürdőrész rendelőkkel, a fedett gyógy- és élményfürdő, a szabadtéri élményfürdő, a szaunák, a $815 \mathrm{~m}^{2}$ vízfelületű beltéri és a $825 \mathrm{~m}^{2}$ vízfelülettel rendelkező kültéri fürdő.

A fejlesztések negyedik ütemében a legfontosabb elem a magasabb minőségű turizmus fejlesztése érdekében a kereskedelmi szálláshelyfejlesztés volt. Ennek keretében megépült a 250 ágyas gyógyszálloda, valamint a Kehida Termál Élmény falu, négy épületben 15 db családi apartmannal és a Hertelendy Ház 24 db standard kétágyas szobával. A kehidakustányi termálvizet 2002-ben az Állami Népegészségügyi és Tisztifőorvosi Szolgálat (ÁNTSZ) gyógyvízzé minősítette.

A fejlesztések eredményeként 2003 márciusában adták át a nemzetközi fürdőturizmusban is korszerűnek mondható Kehida-Termál Gyógy- és Élményfürdőt és a hozzá kapcsolódó kereskedelmi szálláshelyeket. A további fejlesztések önerőből valósultak meg. Kibővítették a Deák éttermet, a 
két kültéri kamikaze csúszdát megépítették, valamint új vendéglátó egységeket létesítettek, mint a pecsenyés és a palacsintázó pavilonok, majd végül kiépült a fürdő északi bejárata.

A fürdővendégek létszámának alakulására már ekkor jelentős hatással voltak a fejlesztések, mivel a beruházást megelőző időszakban évente 120-150 ezer, a fejlesztést követő években 370-410 ezer között változott a fürdővendégek száma. A fürdőfejlesztésnek köszönhetően a községben gyors ütemben épültek ki a szállásférőhelyek fizetővendéglátóhelyek és panziók formájában, melyek jelentősége az önkormányzat további bevételeinek növekedésében is megmutatkozott, így lehetôvé téve a települési infrastruktúra fejlesztését. A fejlesztéseknek köszönhetően az ÁNTSZ 2014-ben a Kehida-Termál Gyógy- és Élményfürdőt gyógyfürdővé minősítette, majd 2016-ben a gyógyfürdőt és közvetlen környezetét „Kehidakustány Gyógyhely” néven gyógyhellyé nyilvánította.

\section{A Kehida-Termál Gyógy- és Élményfürdő részlegei}

A Kehida-Termál Gyógy- és Élményfürdőben a nemzetközi egészségturisztikai igényeknek megfelelően három fürdőszolgáltatási részleget alakítottak ki, a Wellness \& SPA részleget, a Szauna Oázis részleget és a Fürdőrészleget.

A Wellness \& SPA részlegen masszázsok, testkezelések, aromafürdők, szolárium vehetők igénybe, valamint szépségápolási, fitness és sportszolgáltatások érhetők el.

A Szauna Oázis részlegen finn szaunák, aroma-és zeneterápiás kabin, infrakabin, gőzfürdő, Kneipp taposó és pezsgőfürdő található.

A Fürdőrészleg három részből az Élményfürdő részlegből, a Strandfürdő részlegből és a Gyógyfürdő részlegből áll. A fedett háromszintes Élményfürdő részlegen sodró- és ugrómedence, élménymedence, csőcsúszda, gyermekmedence csúszdával és pezsgőfürdő-sziget található. A Strandfürdő részlegen hullámfürdő, hideg úszómedence, meleg úszómedence, kamikaze ikercsúszda, valamint pihenő és napozó teraszok (naturistáknak is) vannak. A Gyógyfürdő részlegen $15 \mathrm{db}$ medence öszszesen $2400 \mathrm{~m}^{2}$ vízfelület áll a fürdővendégek rendelkezésére, melyhez háromhektáros park tartozik. A Gyógyfürdô részlegben található öt db gyógymedence $34-36^{\circ} \mathrm{C}$-os vize a prevenciót, a kurációt és a rehabilitációt szolgálja. A beltéri, üvegfallal elválasztott fürdőcsarnokban található egy kör ülőmedence, valamint egy súlyfürdős és nyakzuhanyos gyógymedence. A Gyógyfürdő részlegben található pihenőszobában ivókút áll, melynek gyógyvize ivókúrára is kiválóan alkalmas, rendszeres fogyasztása emésztési problémákra javallott. A gyógyvizes medencék környezetében nyugalmas, kizárólag felnőttek részére kialakított pihenőterek találhatók.

\section{Anyag és módszer}

A kutatási célom elérése érdekében a kvantitatív kutatási módszerek közül a kérdőíves felmérést (survey) alkalmaztam. A kérdőív a Kehida-Termál Gyógy- és Élményfürdő Fürdőjét felkeresô turisták gyógyfürdő-szolgáltatások igénybevételélének gyakoriságát mérte. További hét kérdés a turisták szocio-demográfiai jellemzőire vonatkozott (Takács, 2016). Az adatgyüjtés eszközeként papír alapú kérdőívet alkalmaztam, melyeket közvetítőkön keresztül juttattam el a megkérdezettekhez. A válaszadók kiválasztása randomizált módon (Babbie, 2017) történt a Kehida-Termál Gyógy- és Élményfürdő Fürdőrészlegében. A válaszadókkal szemben támasztott követelmény a felnőtt kor és a magyar állampolgárság volt. Az adatgyújtésre 2019. augusztus 1. napjától a tervezett 200 darab értékelhetően kitöltött kérdőív eléréséig, vagyis 2019. augusztus 18. napjáig került sor. A kérdőíveket 
értékelhetően kitöltő 200 fő szocio-demográfiai jellemzőit figyelembe véve sikerült elérni a tág értelemben vett, középkorú magyar középosztályt (1. ábra).

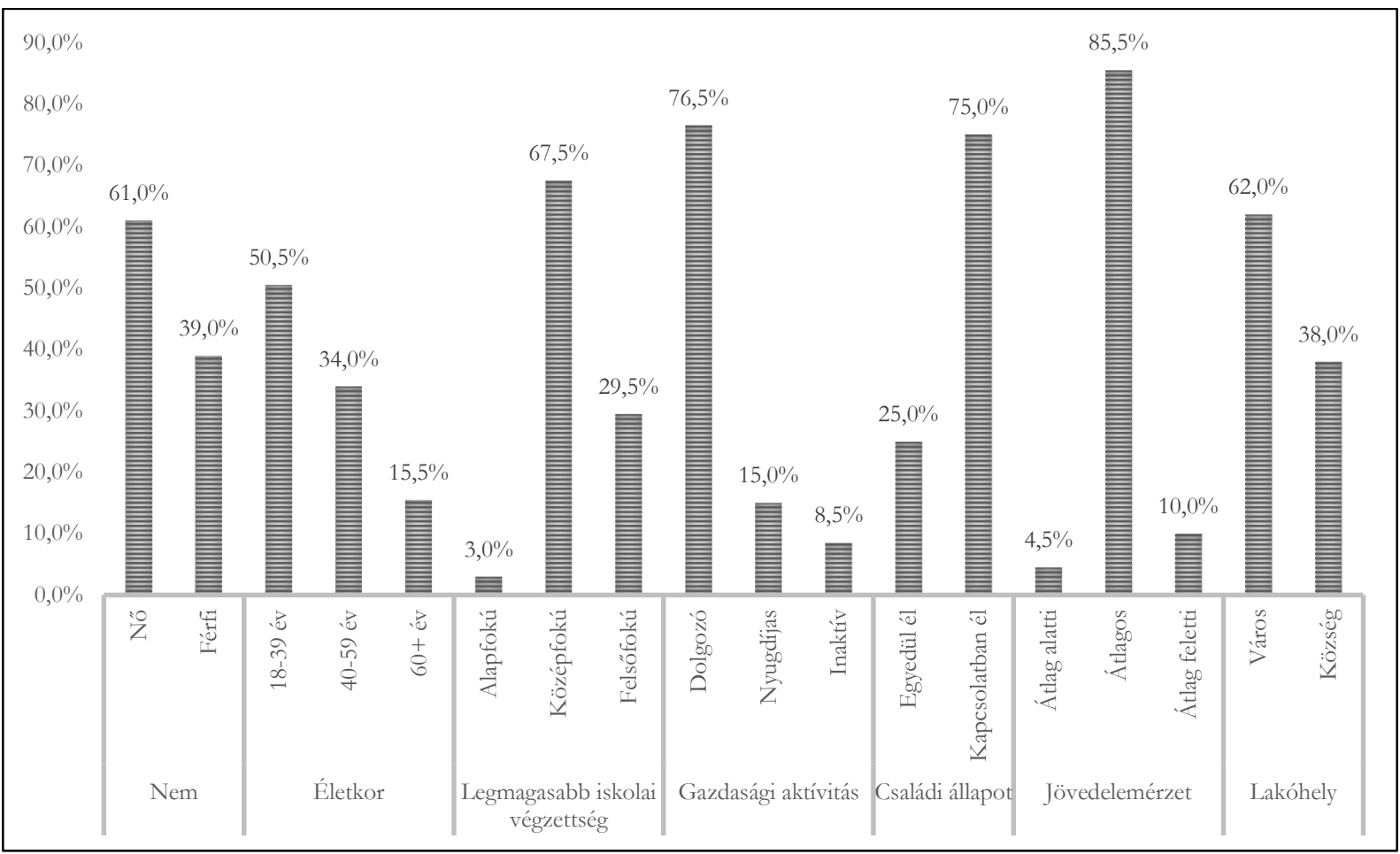

1. ábra: A válaszadók szocio-demográfiai jellemzői $(\mathrm{N}=200)$

Forrás: Saját számitás, saját szerkesz̨tés

A kérdőívet kitöltők (39\% férfi, 61\% nô) életkora alapján 50,5 \%-a 18-39 év, 34,0\%-a 40-59 év közötti, továbbá 15,5\%-a 60 évnél idôsebb volt. Legmagasabb iskolai végzettségüket tekintve 3,0\% alapfokú, 67,5\% középfokú, 29,5\% felsőfokú végzettségủ, gazdasági aktivitásukat tekintve a dolgozó $76,5 \%$, nyugdíjas 15,0\% és munkanélküli 8,5\% személy volt. Családi állapotuk szerint 25\% egyedül, 75\% párkapcsolatban él, 62,0\% városban, 38,0\% községben lakik. Jövedelemérzetük alapján 4,5\% átlag alatti, 85,5\% átlagos, 10,0\% pedig átlag feletti jövedelemmel rendelkezik.

A kvantitatív kutatás megtervezése és végrehajtása során figyelembe vettem a statisztikáról szóló 1993. évi XLVI. törvényt, különös tekintettel annak a statisztikai adatgyújtésére (8-9.S), a hivatalos statisztikai szolgálathoz nem tartozó szervek statisztikai adatgyújtéseire (15-16.§) és a statisztikai adatok nyilvánosságára, védelmére, továbbítására (17-21.』) vonatkozólag.

A gyógyfürdő-igénybevétel gyakoriságának mérése szofisztikált, ötfokozatú Likert skála alkalmazásával történt, ahol az 1-es a „soha”, 2-es a „ritkán”, a 3-as az „időnként”, a 4-es a „gyakran” és az 5-ös a „rendszeresen” választ jelentette. A kapott adatokat a Windows 10 programcsomag SPSS 23.0 verziójú statisztikai elemző programjával dolgoztam fel. Az adatfeldolgozási módszerek közül az egyváltozós leíró statisztikai elemzéseket és a kétváltozós kereszttábla elemzést használtam. Ahol a kontingenciatábla megfelelt a gyakorisági követelményeknek, vagyis az összes cella gyakorisági száma maximum 20\%-ában kevesebb, mint 5, ott a Pearson-féle khi négyzet próbát $\left(\chi^{2}\right)$ alkalmaztam $\mathrm{p}=0,05$ szignifikanciaszinten, a változók közötti összefüggés erősségét a Cramer's V értékkel vizsgálva. Ahol a kontingenciatábla nem felelt meg az elemzési követelményeknek, ott Fisher féle egzakt próbával végeztem el a változók közötti összefüggések feltárását (Vargha, 2015). 


\section{Eredmények}

A Kehida-Termál Gyógy- és Élményfürdőbe járó válaszadók több mint kétharmad része (69,5\%) elkötelezett a Fürdőrészlegben való tartózkodása alatt a gyógyfürdő-szolgáltatások igénybevétele iránt (2. ábra).

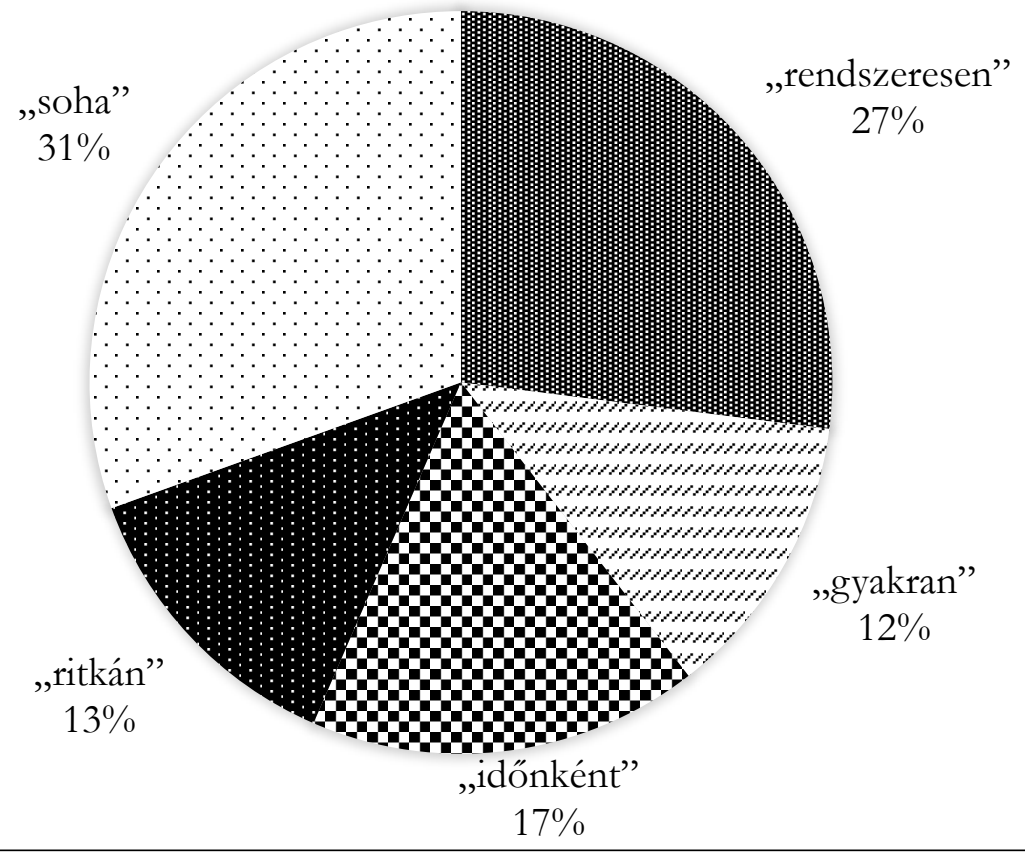

2. ábra: A kehidakustányi fürdőturisták gyógyfürdő-szolgáltatások igénybevétele iránti elkötelezettsége $(\mathbf{N}=200)$

Forrás: Saját számitás, saját sæuerkesztés

Az ábra alapján megállapítható, hogy a Fürdôrészleget látogatók 27,0\%-a „rendszeres” igénybe vevője a gyógyfürdő-szolgáltatásoknak, de ennél többen vannak (30,5\%) azok, akik nem látogatják azt „soha”. A válaszadók több mint egyharmad része (39,5\%) a Gyógyfürdő szolgáltatásait sűrűn (,gyakran”, „rendszeresen”) veszi igénybe.

A Fürdőrészleget látogatók neme és a gyógyfürdő-szolgáltatások igénybevétel-gyakoriságának kontingencia-táblázata megfelelt a gyakorisági követelményeknek, ezért a változók közötti összefüggés-vizsgálat Pearson-féle khi négyzet próbával $\left(\chi^{2}=5,551, \mathrm{df}_{\text {szabadságfok }}=4\right)$ történt. Mivel a khi négyzet próba szignifikanciája $(\mathrm{p}=0,049)$ kisebb, mint 0,05 , ezért elutasításra került a khi négyzet próba alapján a nullhipotézis, vagyis van összefüggés a változók között (H1). A Cramer's V = 0,219 értékű, tehát a változók között közepes erősségű összefüggés van. Míg a férfiak 38,5\%-a rendszeresen, a 14,1\%-a gyakran veszik igénybe a Gyógyfürdő szolgáltatásait, addig a nők között ez 25,4\% és 12,3\%. Tehát a férfiak között magasabb a Gyógyfürdő szolgáltatásait rendszeresen és gyakran igénybe vevők aránya. A férfiak között 19,2\% a gyógyfürdő-szolgáltatásokat időnként igénybe vevők aránya, ugyanez a nők körében csak 15,6\%. Vagyis a férfiak körében magasabb az időnként gyógyfürdő-szolgáltatásokat igénybe vevők aránya. A gyógyfürdő-szolgáltatásokat ritkán igénybe vevők aránya nem tér el jelentősen a férfiak (12,8\%) és a nők (12,3\%) esetében. Míg a nők közül $34,4 \%$ soha nem veszi igénybe a gyógyfürdő-szolgáltatásokat, addig ez a férfiaknál kevesebb, mint 
a fele 15,4\%. Tehát a nők között magasabb a Gyógyfürdő szolgáltatásait soha igénybe nem vevők aránya.

A Fürdőrészleget felkeresők életkora és a gyógyfürdő-szolgáltatások igénybevétel-gyakoriságának kontingencia-táblázata megfelelt a gyakorisági követelményeknek, ezért a változók közötti öszszefüggés-vizsgálat Pearson-féle khi négyzet próbával $\left(\chi^{2}=56,100, \mathrm{df}_{\text {szabadságfok }}=8\right)$ történt. Mivel a khi négyzet próba szignifikanciája $(\mathrm{p}=0,000)$ kisebb, mint 0,05 , ezért elvetésre került a khi négyzet próba alapján a nullhipotézis, vagyis van összefüggés a változók között $(\mathrm{H} 1)$. A Cramer's $\mathrm{V}=0,375$ értékű, tehát a változók között közepes erősségű összefüggés van. A rendszeresen gyógyfürdőszolgáltatásokat igénybe vevők aránya a 60 év felettiek körében a legmagasabb (71,0\%), a 40-59 évesek körében alacsonyabb (33,8\%), a 18-39 évesek körében még ennél is alacsonyabb (15,8\%). Így a 60 év felettiek körében a legmagasabb a Gyógyfürdő szolgáltatásait rendszeresen igénybe vevők aránya. A gyakran gyógyfürdő-szolgáltatásokat igénybe vevők aránya a 18-39 évesek körében a legalacsonyabb (6,9\%), növekvő sorrendben őket követik a 60 év felettiek aránya (12,9\%) és a 40-59 évesek (22,1\%). A gyógyfürdő-szolgáltatásokat időnként igénybe vevők között a legmagasabb a 18-39 évesek aránya (19,8\%), csökkenő sorrendben őket követik a 40-59 évesek (14,7\%) majd a 60 év felettiek aránya (12,9\%). Tehát a gyógyfürdő-szolgáltatásokat idônként igénybe vevők a 18-39 évesek. A gyógyfürdő-szolgáltatásokat ritkán igénybe vevők aránya közel azonos a 18-39 évesek (14,9\%) és a 40-59 évesek (14,7\%) között. A 60 év felettiek körében nincs olyan, aki ritkán veszi igénybe a gyógyfürdő-szolgáltatásokat. A gyógyfürdő-szolgáltatásokat soha igénybe nem vevők aránya a legmagasabb a 18-39 évesek $(42,6 \%)$ között, csökkenő sorrendben óket követik a 4059 évesek $(14,7 \%)$ és a 60 év felettiek (3,2\%). Ennek következtében a 18-39 évesek körében a legmagasabb a Gyógyfürdő szolgáltatásait soha igénybe nem vevők aránya.

A Fürdőrészleget látogatók gazdasági aktivitása és a gyógyfürdő-szolgáltatások igénybevétel-gyakoriságának kontingencia-táblázata nem felelt meg a gyakorisági követelményeknek, ezért a változók közötti összefüggés-vizsgálat Fisher féle egzakt próbával történt $(F=26,925)$. Mivel a Fisher féle egzakt próba szignifikanciája $(p=0,000)$ kisebb, mint 0,05 , ezért elutasitásra került a Fisher féle egzakt próba alapján a nullhipotézis, vagyis van összefüggés a változók között (H1). A Cramer’s $\mathrm{V}=0,303$ értékű, tehát a változók között közepes erősségü összefüggés van. A rendszeresen gyógyfürdő-szolgáltatásokat igénybe vevők aránya a nyugdíjasok között a legmagasabb (73,3\%), jelentősen lemaradva következnek a dolgozók (23,5\%) és a munkanélküliek (17,6\%). Tehát a gyógyfürdőszolgáltatásokat rendszeresen igénybe vevők egyértelmúen a nyugdíjasok. A gyakran gyógyfürdőszolgáltatásokat igénybe vevők között legmagasabb a dolgozók aránya (13,7\%), akiket kis különbséggel követnek a nyugdíjasok csoportja (13,3\%), akiknél jelentősen kevesebb (5,9\%) a munkanélküliek aránya. A gyógyfürdő-szolgáltatásokat időnként igénybe vevők körében a legmagasabb $(18,3 \%)$ a dolgozók aránya, akiket csökkenő sorrendben a munkanélküliek $(17,6 \%)$ és a nyugdíjasok csoportja (10,0\%) követ. A gyógyfürdő-szolgáltatásokat ritkán igénybe vevők aránya a legnagyobb $(15,0 \%)$ a dolgozók körében, akiket a munkanélküliek követnek (11,8\%). A nyugdíjasok körében nincs olyan, aki ritkán veszi igénybe a gyógyfürdő-szolgáltatásokat. A gyógyfürdő-szolgáltatásokat soha igénybe nem vevők aránya a legmagasabb $(47,1 \%)$ a munkanélküliek között, csökkenő sorrendben őket követik a dolgozók (29,4\%) és jelentősen lemaradva a nyugdíjasok (3,3\%). Ennek következtében a munkanélküliek között a legmagasabb a Gyógyfürdő szolgáltatásait soha igénybe nem vevők aránya.

A Fürdőrészleget felkeresôk iskolai végzettsége és a gyógyfürdő-szolgáltatások igénybevétel-gyakoriságának a kontingencia-táblázata nem felelt meg a gyakorisági követelményeknek, ezért a változók közötti összefüggés-vizsgálat Fisher féle egzakt próbával történt $(F=10,353)$. Mivel a Fisher féle egzakt próba szignifikanciája $(\mathrm{p}=0,185)$ nagyobb volt, mint 0,05 , ezért elfogadásra került a 
Fisher féle egzakt próba alapján a nullhipotézis (H0), vagyis nem mutatható ki összefüggés a változók között.

A Fürdőrészleget látogatók lakhelye és a gyógyfürdő-szolgáltatások igénybevétel-gyakoriságának kontingencia-táblázata megfelelt a gyakorisági követelményeknek, ezért a változók közötti összefüggés-vizsgálat Pearson-féle khi négyzet próbával $\left(\chi^{2}=3,381, \mathrm{df}_{\text {szabadságfok }}=4\right)$ történt. Mivel a khi négyzet próba szignifikanciája $(\mathrm{p}=0,496)$ nagyobb, mint 0,05 , ezért elfogadásra került a khi négyzet próba alapján a nullhipotézis (H0), vagyis nem mutatható ki összefüggés a változók között.

A Fürdőrészleget felkeresők családi állapota és a gyógyfürdő-szolgáltatások igénybevétel-gyakoriságának kontingencia-táblázata megfelelt a gyakorisági követelményeknek, ezért a változók közötti összefüggés-vizsgálat Pearson-féle khi négyzet próbával $\left(\chi^{2}=15,835, \mathrm{df}_{\text {szabadsaǵgok }}=4\right)$ történt. Mivel a khi négyzet próba szignifikanciája $(\mathrm{p}=0,003)$ kisebb, mint 0,05 , ezért elutasításra került a khi négyzet próba alapján a nullhipotézis, vagyis van összefüggés a változók között $(\mathrm{H} 1)$. A Cramer's $\mathrm{V}=0,281$ értékű, tehát a változók között közepes erősségű összefüggés van. A párkapcsolatban élők között 36,7\% a gyógyfürdő-szolgáltatásokat rendszeresen igénybe vevôk aránya, az egyedül élők körében 12,0\%. Ezek szerint a párkapcsolatban élők körében magasabb a rendszeres gyógyfürdő-szolgáltatásokat igénybe vevők aránya, mint az egyedülállók között. A gyógyfürdő-szolgáltatásokat gyakran igénybe vevők leginkább (14,0\%) az egyedül élők, mint a párkapcsolatban élők $(12,7 \%)$. Tehát az egyedül élők veszik gyakran igénybe a gyógyfürdő-szolgáltatásokat. A párkapcsolatban élők között 17,3\% a gyógyfürdő-szolgáltatásokat időnként igénybe vevők aránya, az egyedül élők körében ez 16,0\%. Ezek alapján a párkapcsolatban élők körében magasabb az időnként gyógyfürdő-szolgáltatásokat igénybe vevők aránya, mint az egyedül élőké. A gyógyfürdő-szolgáltatásokat ritkán igénybe vevők aránya az egyedülállók között nagyobb (24,0\%), mint a párkapcsolatban élők $(8,7 \%)$ körében. Tehát az egyedülállók ritkán veszik igénybe a gyógyfürdő-szolgáltatásokat. Míg az egyedül élők 34,0\%-a, addig a párkapcsolatban élőknek csak 24,7\%-a az, aki soha nem veszi igénybe a Gyógyfürdő szolgáltatásait. Emiatt az egyedül élőkre jellemző inkább, hogy soha nem veszik igénybe a Gyógyfürdő szolgáltatásait.

A Fürdőrészleget látogatók családi jövedelemszintje és a gyógyfürdő-szolgáltatások igénybevételgyakoriságának a kontingencia-táblázata nem felelt meg a gyakorisági követelményeknek, ezért a változók közötti összefüggés-vizsgálat Fisher féle egzakt próbával történt $(\mathrm{F}=3,992)$. Mivel a Fisher féle egzakt próba szignifikanciája $(\mathrm{p}=0,826)$ nagyobb, mint 0,05 , ezért elfogadásra került a nullhipotézis $(\mathrm{H} 0)$, vagyis nem mutatható ki összefüggés a változók között.

\section{Köveztetések és javaslatok}

A kérdőíveket értékelhetően kitöltő 200 válaszadó szocio-demográfiai jellemzői alapján sikerült elérni a tág értelemben vett középkorú magyar középosztályt. Tehát a minta korlátozottan reprezentatív, mivel az alapsokaság nem ismert. A Fürdőrészleget látogatók neme és a gyógyfürdő-szolgáltatások igénybevétel-gyakoriságának kereszttábla adataiból az következik, hogy a férfiak gyakrabban veszik igénybe a gyógyfürdő-szolgáltatásokat, mint a nők. Az összefüggés-vizsgálat alapján közepes erősségú összefüggés mutatható ki a Fürdőrészleget látogatók neme és a gyógyfürdő-szolgáltatások igénybevétel-gyakorisága között. A Fürdőrészleget felkeresők életkora és a gyógyfürdőszolgáltatások igénybevétel-gyakoriságának kereszttábla adatai alapján megállapítást nyert, hogy leggyakrabban a 60 év felettiek veszik igénybe a gyógyfürdő-szolgáltatásokat, majd az folyamatos csökken a 40-59 évesek és a 18-39 évesek körében. Az összefüggés-vizsgálat alapján közepes erősségű 
összefüggés mutatható ki a Fürdőrészleget látogatók életkora és a gyógyfürdő-szolgáltatások igénybevétel-gyakorisága között. A Fürdőrészleget felkeresők gazdasági aktivitása és a gyógyfürdő-szolgáltatások igénybevétel-gyakoriságának kereszttábla adataiból az következik, hogy a nyugdíjasok gyakrabban veszik igénybe a gyógyfürdô-szolgáltatásokat, mint a dolgozók vagy munkanélküliek csoportja. Az összefüggés-vizsgálat alapján közepes erôsségú összefüggés mutatható ki a Fürdőrészleget látogatók gazdasági aktivitása és a gyógy fürdő-szolgáltatások igénybevétel-gyakorisága között. A Fürdőrészleget látogatók iskolai végzettsége és a gyógyfürdő-szolgáltatások igénybevételgyakorisága közötti összefüggés statisztikailag nem bizonyított, ezért nem mutatható ki összefüggés. A Fürdőrészleget felkeresők lakhelye és a gyógyfürdő-szolgáltatások igénybevétel-gyakorisága közötti az összefüggés statisztikailag nem bizonyított, ezért nem mutatható ki összefüggés. A Fürdőrészleget látogatók családi állapota és a gyógyfürdő-szolgáltatások igénybevétel-gyakoriságának kereszttábla adataiból az következik, hogy a párkapcsolatban élők gyakrabban veszik igénybe a gyógyfürdő-szolgáltatásokat, mint az egyedül élők. Az összefüggés-vizsgálat alapján közepes erősségű összefüggés mutatható ki a Fürdőrészleget látogatók családi állapota és a gyógyfürdő-szolgáltatások igénybevétel-gyakorisága között. A Fürdőrészleget felkeresők családi jövedelemszintje és a gyógyfürdő-szolgáltatások igénybevétel-gyakorisága közötti az összefüggés statisztikailag nem bizonyított, ezért nem mutatható ki összefüggés.

A kutatás célkitűzése alapján végzett felmérés segítségével kapott összefüggés-vizsgálati eredményekből a Kehida-Termál Gyógy- és Élményfürdő gyógyfürdő-szolgáltatásainak igénybevételére vonatkozólag hat olyan megállapítás következik, amely új, tudományosan bizonyított eredménynek tekinthető:

- Bizonyított, hogy a férfiak a nőknél gyakrabban veszik igénybe a Fürdőrészlegen belül a gyógy fürdő-szolgáltatásokat (1).

- Bizonyított, hogy minél idősebb felnőtt valaki, annál valószínúbb, hogy gyakrabban veszi igénybe a Fürdőrészlegen belül a gyógyfürdő-szolgáltatásokat (2).

- Bizonyított, hogy már a 40-59 éves korosztály is nagyon gyakran veszi igénybe a Fürdőrészlegen belül a gyógyfürdő-szolgáltatásokat (3).

- Bizonyított, hogy minél több diszkrecionális szabad ideje van valakinek, annál valószínúbb, hogy gyakrabban veszi igénybe a Fürdőrészlegen belül a gyógyfürdő-szolgáltatásokat (4).

- Bizonyított, hogy a párkapcsolatban élők az egyedül élőknél gyakrabban veszik igénybe a Fürdőrészlegen belül a gyógyfürdő-szolgáltatásokat (5).

- A nagy mintán végzett elemzés eredményei igazolják a további vizsgálatok létjogosultságát, a gyógy fürdő-szolgáltatások igénybevétel-gyakoriságának összefüggés-vizsgálatát a Fürdőrészleget látogatók iskolai végzettsége, lakhelye és családi jövedelemszintje között (6).

Ezek az új, tudományosan bizonyított eredmények segítséget nyújthatnak a turizmus tervezőinek, a turizmusmarketing szakembereknek az új piaci lehetőségek jobb kihasználásában, a fürdőmenedzsereknek a vendégigények jobb kielégíthetőségében és a gazdaságilag hatékonyabb fürdőüzemeltetésben.

\section{Hivatkozott források}

[1.] Baji P. - Brodszky V. - Rencz F. - Boncz I. - Gulácsi L. - Péntek M. (2015): A magyar lakosság egészségi állapota 2000 és 2010 között. Orvosi Hetilap, 156(50), 2035-2044.

[2.] Bauer, I. (2008): The health impact of tourism on local and indigenous populations in resource-poor countries. Travel medicine and infectious disease, 6(5), 276-291. 
[3.] Biró M. - Pucsok J. M. - Hidvégi P. - Molnár A. - Mikhárdi S. - Lenténé Puskás A. (2019): A magyarországi és az Észak- alföldi fürdők jellemzőinek, forgalmának és a fürdők által nyújtott szolgáltatásoknak az elemzése In: Balogh L. (szerk.) Sport és társadalom. Debrecen, Debreceni Egyetem Sporttudományi Koordinációs Intézet, pp. 18-28.

[4.] Boros Sz. - Mondok A. - Várhelyi T. (2012): Az Egészségturiz̨mus szolgáltatásai és menedzsmentje. Szolnoki Főiskola, p. 386.

[5.] Botos J. - Kovács K. (2018): Egészségi állapot. Demográfiai portré. pp. 103-126.

[6.] Budai Z. - Székács O. (2001): A magyar egészségturisztikai kínálat alakítása a különböző célcsoportok igényei szerint. Turiz̨mus Bulletin, (4), 3-6.

[7.] Bujdosó Z. - Györki M. (2011): A biztonság szerepe a turizmusfejlesztésben. Acta Carolus Robertus 1(2), 45-55.

[8.] Bujdosó Z. - Gyurkó Á. - Benkő B. (2019): Tourism development in Hungary on the example of Northern Hungary Region. Folia Geographica 61(2), 86-103.

[9.] Bujdosó Z. (2016): A turizmus és a területfejlesztés kapcsolatrendszere Magyarországon. In: Kókai S. (szerk.) A változó világ XXI. századi kibivásai: tanulmánykötet Prof. Dr. Hanusz. Arpád egyetemi tanár 70. születésnapja tiszteletére. Nyíregyházi Egyetem Turizmus és Földrajztudományi Intézet, pp. 63-76.

[10.] Dávid L. - Tóth G. - Bujdosó Z. - Herneczky A. (2007): A turizmus és a regionális versenyképesség kapcsolatának mutatói a Mátravidék példáján keresztül. Észak-Magyarországi Stratégiai Füretek (4)1 3-20.

[11.] Dominkovit P. - Káli Cs. - Kvassay J. - Molnár A. (2007): Kebida. Száz Magyar Falu Könyvesház, Budapest, p. 208.

[12.] Fejér L. (2015): Kehidakustány a frissítő gyógyfürdő. Természet Gyógyász Magaz̨in, 21(5), 30-32.

[13.] Garcia-Altes, A. (2005): The development of health tourism services. Annals of tourism research, 32(1), 262-266.

[14.] Guld, Zs., Rácz, A., Tima, H., Kállay, M., Nyitrainé Sárdy, D. (2019): Effects of aging in oak barrels on the trans-resveratrol and anthocyanin concentration of red wines from Hungary Acta Alimentaria: An International Journal Of Food Science 48(3), 349-357.

[15.] Hojcska, Á. E. (2017a): Medical bath treatments with the support of national health insurance fund, in hungarian spa towns: Fürdőgyógykezelések az Országos Egészségbiztosítási Pénztár támogatásával a magyar fürdővárosokban. In: Szabó, Z. (szerk.) The values of spa towns. Szentes, pp. 16-35.

[16.] Hojcska Á. E. (2017b): Rekreáció a fürdővárosok vonzásában: Mezítlábas sétány Reziben Kneipp nyomdokain. Recreation 7(2) Közép-Kelet-Európai Rekreációs Társaság, 13-16. DOI:10.21486/recreation.2017.7.2.1

[17.] Hojcska, Á. E. (2019a): Medical bath treatment protocol and patient turnover data by a hungarian medical spa bath example. In: Reisinger, A. et al. (eds): „Kulturális gazdaság”. elektronikus kötet, Győr, Széchenyi István Egyetem, p. 19.

[18.] Hojcska Á. E. (2019b): A fürdőgyógyászati intézményrendszer egyenlőtlenségei Magyarországon. In: Kőszegi I. R. (szerk.): Versenyképesség és innováció. Kecskemét, Neumann János Egyetem, pp. 858-864.

[19.] Jandala Cs. - Sándor T. - Gondos B. (2010): Az egészségturizmus a turizmuspolitika fókuszában - A fürdőkultúra szerepe a turisztikai fejlesztésekben. Turizmus Bulletin, 14(4), 19-28.

[20.] Kim, S. H. - Kim, S. - Huh, C. - Knutson, B. (2010): A predictive model of behavioral intention to spa visiting: an extended theory of planned behavior. International CHRIE Conference-Refereed Track, University of Massachusetts, Amherst, p. 9. 
[21.] Kincses Gy. (2014): Az egészségturizmus helye és szerepe a balneoterápiában. In: Bender T. (szerk.): Balneoterápia és hidroterápia. Medicina Könyvkiadó, Budapest, pp. 145-152.

[22.] Kopp M. (2007): Életesélyeink - életminöség, stressz, megkürqués. Pszinapszis Kiadó, Budapest, pp. $13-15$.

[23.] Kraft, F. B. - Goodell, P. W. (1993): Identifying the health conscious consumer. Marketing Health Services, 13(3), p. 18.

[24.] KSH (2013): A gyógyturizmusban érintett települések Magyarországon. Központi Statisztikai Hivatal, Budapest, p. 22.

[25.] Kulcsár D. (2013): Turizmusföldrajz. In: Jeney, L., Kulcsár, D., Tózsa, I. (szerk.): Gazdaságföldrajzi tanulmányok közgazdászoknak. Budapesti Corvinus Egyetem, Gazdaságföldrajzi és Jövőkutatási Tanszék, Budapest, pp.153-173.

[26.] Li, H. - Yang, X. - Liu, H. (2017): The Basic Characteristics and Development Models of Health Tourism. Journal of West Anhui University, (5), p. 25.

[27.] Lövei-Kalmár K. (2018): Magyarországi fürdők keresletének és kínálatának jellemzői régiónként. In: Szabó Z. (szerk.) Fürdôvárosok fejlódése. Túrkeve, pp. 85-103.

[28.] Mészáros T. L. (2007): Kehidakustány. Mészi Kiadó, Zalaegerszeg, p. 48.

[29.] Mundruczó Gy.-né - Szennyessy J. (2005): A Széchenyi-terv egészségturisztikai beruházásainak gazdasági hatásai. Turiz̧mus Bulletin, 9(3), 30-41.

[30.] Mühlhausen, C. (2001): Future health. Zukunftsinstitut, Bonn, pp. 5-27.

[31.] Nemes A. (2009): Az állam szerepe a turizmusban. Vezetéstudomány, 40(5), 53-67.

[32.] Németh P. - Farkas L. (2005): Jelentés a helyi önkormányzati fürdök - kiemelten a gyógyfürdök helyzete, fejlesztésének lehetöségei, hatása az idegenforgalomra és a turizmusra. Állami Számvevőszék, Budapest, p. 79.

[33.] Printz-Markó E. - Albert-Tóth A. (2018): Az egészségturizmus fogalomrendszerének modellezése kiválasztott nyugat-dunántúli fürdőtelepülések mintáján keresztül. Polgári Sẓmle 14(13), 205-220.

[34.] Printz-Markó, E. (2019): Opportunities for Service Development along the Water-based Health Tourism Model Based on the Four Ancient Elements. In: Hojcska Á. E. (eds.) Changing Spa Towns. Tata, Magyar Fürdővárosok Szövetsége. pp. 87-111.

[35.] Riskin, C. (1996): Social development, quality of life and the environment. China's Economic Future: Challenges to US Policy, pp. 361-380.

[36.] Szóládi J. (2003): Kehidakustány: településportré a második és a barmadik éveared fordulóján. Balaton Info Center, Keszthely, p. 48.

[37.] Takács Sz. (2016): Bevę̧tés a matematikai statiştikába, elmélet és gyakorlat. Antarész Kiadó, Budapest, p. 355.

\section{Szerző}

Dr. Szabó Zoltán, PhD

ORCID 0000-0002-1088-8416

adjunktus

Magyar Agrár- és Élettudományi Egyetem, Georgikon Campus

Szabo.Zoltan.dr@uni-mate.hu 